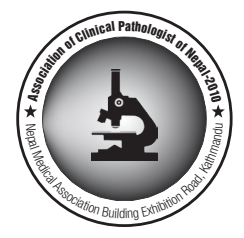

\title{
Analysis of sickle hemoglobin
}

\author{
Shrestha $\mathrm{A}^{1}$, Karki $\mathrm{S}^{1}$

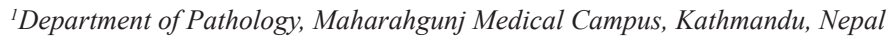

\section{Keywords: \\ Electrophoresis; \\ Hemoglobin ; \\ Hemoglobin S; \\ Sickle}

\begin{abstract}
Background: Sickle Hemoglobin is the most common pathological hemoglobin mutation worldwide which forms sickle shape or elongated forms on deoxygenation. According to malaria hypothesis, there is resistance against malaria by the heterozygous carrier state. There is spread of $\mathrm{Hb} \mathrm{S}$ allele from the highly malarial regions to most other regions worldwide. The study was conducted as Sickle Hemoglobin has been frequently seen in our institute.
\end{abstract}

Materials and Methods: This study was conducted in the department of pathology, Maharajgunj medical campus, Tribhuwan University Teaching hospital, from January 2011 to January 2013. All the relevant data were obtained from the archives of the department. Hemoglobin electrophoresis was performed by Cellulose Acetate Electrophoresis at alkaline pH Method. Sickling test was done using sodium dithionite.

Results: A total of 35 cases were diagnosed as sickle cell disorder. The male: female ratio was 2.5:1with the commonest age group 11-20 years (42.8\%). Sixty percent showed hemoglobin between 6-8 gm/ dl. Tharu, Chaudhary and Tharu, Rana (91.3\%) were the commonest ethnic group with both sickle cell anemia and trait. Lama, Neupane and Baral suffered only from trait. Mean corpuscular volume ranged from 82 to $94 \mathrm{fL}$. On peripheral blood smear reversible and irreversible sickle cells were present in 88.56 $\%$ of cases and $11.42 \%$ were devoid of sickle cells. Sickling test was positive in all cases. On cellulose acetate electrophoresis $22(62.85 \%)$ cases had $\mathrm{Hb} \mathrm{S}, \mathrm{Hb} \mathrm{F}$ and $\mathrm{Hb} \mathrm{A} 2$ or $\mathrm{HbS}$ and $\mathrm{Hb} \mathrm{A} 2$ where as $13(37.1 \%)$ showed $\mathrm{Hb} \mathrm{S}, \mathrm{Hb} \mathrm{A}$ and $\mathrm{Hb} \mathrm{A} 2$ variants.

Conclusion: The commonest ethnic group of Tharus(91.3\%), Chaudhary and Rana are from Terai region of Nepal which is a malarial zone. However $8.4 \%$ of cases were seen in other ethnic group who are from non-endemic region.

\section{INTRODUCTION}

Sickle Hemoglobin ( $\mathrm{Hb} \mathrm{S}$ ) is an abnormal variant of hemoglobin in which there is substitution of adenine in sixth codon of beta gene (GAG-GTG), thereby encoding valine instead of glutamic acid in sixth position of beta chain. On de-oxygenation of red blood cells, $\mathrm{Hb} \mathrm{S}$ forms scattered to aggregates of fibers that fill the cell and distorts into sickle shape or elongated forms. Upon oxygenation, reversible

\footnotetext{
Correspondence:

Dr. Anjan Shrestha, $M D$

Department of Pathology Maharajgunj Medical Campus,

Kathmandu, Nepal.Email:anz_shr_path@yahoo.com
}

sickle cells regain normal red cells shape. Irreversible sickle cells are permanently stabilized in abnormal crescent or oval forms. Sickling of red cells can result into anemia, crises and organ injury. ${ }^{1}$

$\mathrm{Hb} \mathrm{S}$ is the most common pathological hemoglobin mutation worldwide. AS individuals are (heterozygotes) are usually asymptomatic and SS individuals (Homozygotes) suffer from sickle cell anemia. According to malarial hypothesis, there is resistance against malaria by the heterozygous carrier state. There is spread of $\mathrm{Hb} \mathrm{S}$ allele from the highly malarious regions to most other regions worldwide. ${ }^{2}$ The 
main factors which are believed to play a major role in the increased frequencies of $\mathrm{Hb} \mathrm{S}$ include:

i) consanguinity ii) malaria hypothesis iii) large sibship size and iv) migration. ${ }^{3}$

The highest prevalence of $\mathrm{Hb} \mathrm{S}$ is seen in blacks from tropical Africa who participated in slave trade. $\mathrm{Hb} \mathrm{S}$ is also seen in Mediterranean basin, Saudi Arabia and parts of India. Approximately $45 \%$ of the population, in some parts of Africa have sickle cell trait and 8\% of blacks in United states carry sickle gene. It has been recognized that sickle cell trait has its highest in areas that are hyperendemic for malaria. It suggests that $\mathrm{Hb} \mathrm{S}$ afforded selective protection against lethal forms of malaria. ${ }^{1}$

The study was conducted as to identify the burden of Sickle Hemoglobin among patients visiting in Maharajgunj Medical campus, Tribhuwan University Teaching Hospital.

\section{MATERIALS AND METHODS}

This retrospective cross-sectional study was done in the This retrospective study was conducted in the Department of pathology, Maharajgunj medical campus, Tribhuwan University Teaching hospital, for a period of two years, from January 2011 to January 2013. Pertinent data including ethnicity, hemoglobin, mean corpuscular volum (MCV), peripheral blood smear for sickle cells, sickling test and Hemoglobin electrophoresis were obtained from the archives of the department. Hemoglobin electrophoresis was performed in this department by Cellulose Acetate Electrophoresis at alkaline $\mathrm{pH}$ Method. Sickling test was done using sodium dithionite.

\section{RESULTS}

During the study period, a total of 35 cases were diagnosed as sickle cell disorder. Among these, males were more commonly affected than females with male: female ratio of 2.5:1. Age ranged from 1-40 years with most common age group being 11-20 years of age with 15 (42.8\%) cases. Correlation of hemoglobin level according to age and sex is shown in table 1. Maximum number of cases i.e. 21/35 cases showed hemoglobin between 6-8 gm/dl. Single case $(2.85 \%)$ of male was seen within the lowest hemoglobin ranging 3-5 gm/dl in the age group of 31-40 years of age. In all age groups and in different hemoglobin levels males were more commonly affected than females.

It was found that Tharu (Chaudhary; $82.8 \%$ ) was the most common ethnic group with this disorder followed by Tharu (Rana; 8.5\%). The disorder was also infrequently found in other ethnic groups/caste including Lama, neupane and Baral (Table 3). Tharus were found to have both sickle cell anemia and trait whereas Lama, Neupane and Baral suffered only from trait.

In this study, all cases had MCV within normal limits and ranged from 82 to $94 \mathrm{fL}$. On peripheral blood smear there were presence of reversible sickle cells (holly leaf cells) in $22.85 \%$ cases; Irreversible sickle cells (fig. 2 ) were $65.71 \%$ and $11.42 \%$ case was devoid of sickle cells. Sickling test (fig. 3) was positive in all cases. On cellulose acetate electrophoresis $22(62.85 \%)$ cases were found to have $\mathrm{Hb}$ $\mathrm{S}, \mathrm{Hb} \mathrm{F}$ and $\mathrm{Hb} \mathrm{A} 2$ or $\mathrm{Hb} \mathrm{S}$ and $\mathrm{Hb} \mathrm{A} 2$ where as $13(37.1 \%)$ were found to have $\mathrm{Hb} \mathrm{S}, \mathrm{Hb} \mathrm{A}$ and $\mathrm{Hb} \mathrm{A} 2$ variants.

\section{DISCUSSION}

In our study there were males more than females with M: F ratio 2.5:1. Similar results were seen in other study as well. ${ }^{4,5}$ Shrikhade AV et $\mathrm{al}^{6}$ found maximum number $(61.36 \%)$ of males reported up to 14 years of age, where as maximum number $(62.16 \%)$ of females was reported in reproductive age groups. Our study shows that maximum number $(37.14 \%)$ of males were in group of $11-20$ years of age whereas maximum number (11.42\%) females were in the groups of $0-10$ years of age.

Kamble et $\mathrm{al}^{4}$ found that $63 \%$ of patients were below 5 years of age and Rao et $\mathrm{al}^{5}$ found patients age range of 5-15 years

Table 1: Correlation of Hemoglobin level according to age and sex wise distribution of patients.

\begin{tabular}{|c|c|c|c|c|c|c|}
\hline \multirow{2}{*}{$\mathrm{Hb}$} & \multirow{2}{*}{ Sex } & \multicolumn{4}{|c|}{ Age in years } & \multirow{2}{*}{ Total } \\
\hline & & $0-10$ & $11-20$ & $21-30$ & $31-40$ & \\
\hline \multirow[t]{2}{*}{$3-5$} & Male & - & - & - & 1 & $1(2.85 \%)$ \\
\hline & Female & - & - & - & 0 & $0(0.00 \%)$ \\
\hline \multirow[t]{2}{*}{$6-8$} & Male & 2 & 9 & 4 & 0 & $15(42.85 \%)$ \\
\hline & Female & 2 & 1 & 2 & 1 & $6(17.14 \%)$ \\
\hline \multirow[t]{2}{*}{$9-11$} & Male & 2 & 4 & 1 & 2 & $9(25.71 \%)$ \\
\hline & Female & 2 & 1 & 0 & 1 & $4(11.42 \%)$ \\
\hline \multirow[t]{3}{*}{ Total } & Male & 4 & 13 & 5 & 3 & $25(71.42 \%)$ \\
\hline & Female & 4 & 2 & 2 & 2 & $10(28.57 \%)$ \\
\hline & & $8(22.8 \%)$ & $15(42.85 \%)$ & $7(20 \%)$ & $5(14.28 \%)$ & $35(100 \%)$ \\
\hline
\end{tabular}


Table 2. Distribution of sickle cell disorder in different ethnic groups.

\begin{tabular}{|c|c|c|c|c|c|c|}
\hline \multirow[t]{2}{*}{ Disorder } & \multicolumn{4}{|c|}{ Ethnic groups/caste } & \multirow[b]{2}{*}{ Baral } & \multirow{2}{*}{ Total } \\
\hline & Chaudhary & Lama & Rana & Neupane & & \\
\hline $\begin{array}{l}\text { Sickle cell anemia } \\
(\mathrm{Hb} \mathrm{SS})\end{array}$ & 21 & 0 & 1 & 0 & 0 & $22(62.8 \%)$ \\
\hline $\begin{array}{l}\text { Sickle cell trait } \\
\text { (Hb AS) }\end{array}$ & 8 & 1 & 2 & 1 & 1 & $13(37.1 \%)$ \\
\hline Total & $29(82.8 \%)$ & $1(2.8 \%)$ & $3(8.5 \%)$ & $1(2.8 \%)$ & $1(2.8 \%)$ & $35(100 \%)$ \\
\hline
\end{tabular}

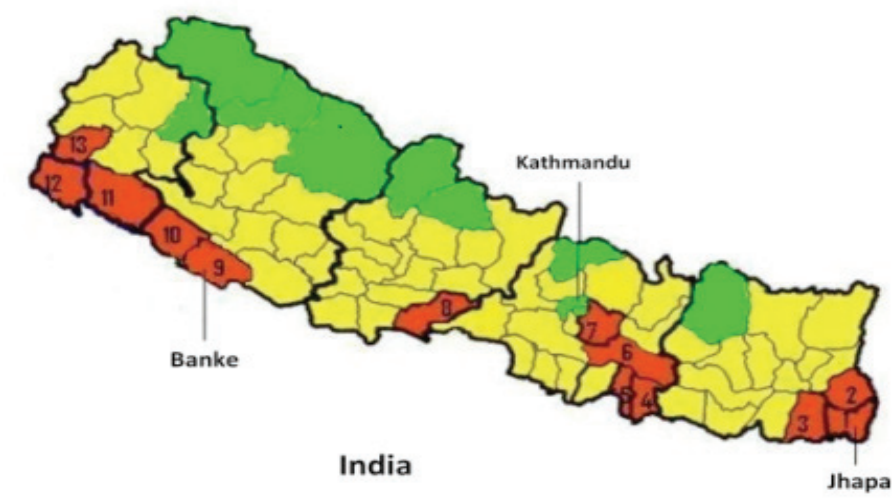

Figure 1: Red: Western and central Terai region of Nepal, which is high malarial zone shelters Tharus.

of age. Whereas in this study, age ranged from 1-40 years with most common age group was between 11-20 years of age.

In this study, maximum number of cases $(n=21 ; 60) \%$ showed hemoglobin between 6-8 gm/dl and similarly other study found that average $\mathrm{Hb}$ observed in males was 7.11 $\mathrm{gm} / \mathrm{dl}$ while that in females was $6.75 \mathrm{gm} / \mathrm{dl}{ }^{6}$

Mean corpuscular volume was within normal range i.e average of $85.5 \mathrm{fL}$ in our study. Similar result was seen in other study i.e MCV in males is 85 and in females $89.8 .^{6}$

On peripheral blood smear reversible sickle cells were seen in 8 cases $(22.85 \%) \%$ and irreversible sickle cells in 23 cases $(65.71 \%)$. However, 4 cases $(11.42 \%)$ were devoid

\begin{tabular}{|c|c|c|c|}
\hline \multirow{2}{*}{$\begin{array}{l}\text { Ethnic } \\
\text { groups }\end{array}$} & \multicolumn{2}{|c|}{ Hemoglobin variants } & \multirow[b]{2}{*}{ Total } \\
\hline & $\begin{array}{c}\mathrm{Hb} \mathrm{S}, \mathrm{Hb} F, \mathrm{Hb} \mathrm{A} 2 \\
\text { or } \mathrm{HbS}, \mathrm{Hb} \mathrm{A} 2\end{array}$ & $\begin{array}{l}\mathrm{Hb} \mathrm{S}, \mathrm{Hb} \mathrm{A}, \\
\mathrm{Hb} \mathrm{A} 2\end{array}$ & \\
\hline Chaudhary & $21(60 \%)$ & $8(22.85 \%)$ & $29(82.85 \%)$ \\
\hline Lama & $0(0.00 \%)$ & $1(2.85 \%)$ & $1(2.85 \%)$ \\
\hline Rana & $1(2.85 \%)$ & $2(5.71 \%)$ & $3(8.57 \%)$ \\
\hline Neupane & $0(0.00 \%)$ & $1(2.85 \%)$ & $1(2.85 \%)$ \\
\hline Baral & $0(0.00 \%)$ & $1(2.85 \%)$ & $1(2.85 \%)$ \\
\hline Total & $22(62.85 \%)$ & $13(37.14 \%)$ & $35(100 \%)$ \\
\hline
\end{tabular}

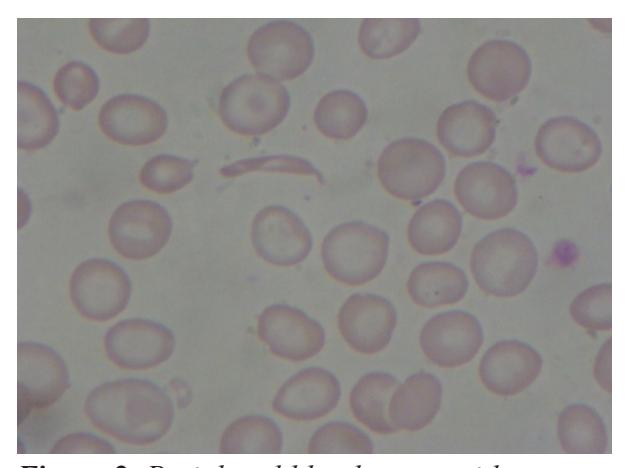

Figure 2: Peripheral blood smear with presence of sickle cell (Wright Stain, X 1000).

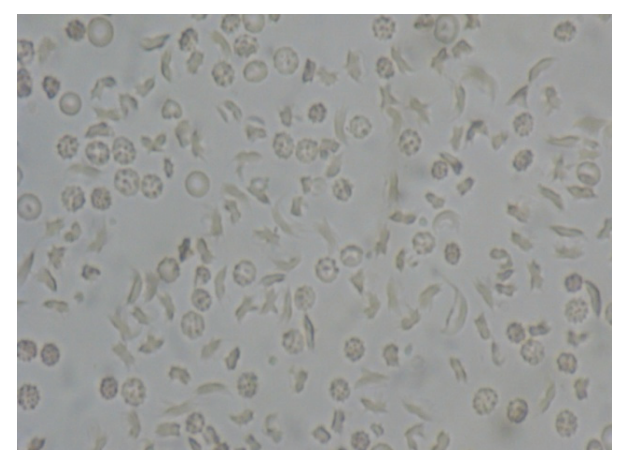

Figure 3: Sickling test showing reversible and irreversible sickle cells (Wright Stain, X 100).

of sickle cells. Sickling test was positive in all cases. Five cases studied by Shukla RN et al observed presence of sickle cells and positive for sickling test in all 5 cases. $^{7}$

On acetate agar electrophoresis $22(62.85 \%)$ cases were found to have sickle cell disease $(\mathrm{Hb} \mathrm{S}, \mathrm{Hb} \mathrm{A} 2$ and $\mathrm{Hb} \mathrm{F}$ or $\mathrm{Hb} \mathrm{S}$ and $\mathrm{Hb} \mathrm{A} 2)$ where as $13(37.1 \%)$ were found to have sickle cell trait ( $\mathrm{Hb} \mathrm{A}, \mathrm{Hb} \mathrm{S}, \mathrm{Hb}$ A2). Study done by Kamble $\mathrm{M}$ et all observed $61.6 \%$ cases of $\mathrm{Hb} \mathrm{SS}$ and $38.4 \%$ cases of $\mathrm{Hb} \mathrm{AS}{ }^{4}$

It was found that Tharu (Chaudhary; $82.8 \%$ ) was the most common ethnic group with this disorder followed by Tharu( Rana; $8.5 \%$ ). The disorder was also infrequently found in other ethnic groups including Lama, neupane and Baral (Table 3). Tharu (Chaudhary and Rana) were found to have both $\mathrm{Hb} \mathrm{SS}$ and $\mathrm{Hb}$ AS where as Lama, Neupane and 


\begin{tabular}{|c|c|c|}
\hline PBS & $\begin{array}{c}\text { Sickling test } \\
\text { Positive }\end{array}$ & Total \\
\hline ISC & 23 & $23(65.71 \%)$ \\
\hline $\mathrm{RSC}$ & 8 & $8(22.85 \%)$ \\
\hline No SC & 4 & $4(11.42 \%)$ \\
\hline Total & $35(100 \%)$ & $35(100 \%)$ \\
\hline
\end{tabular}

ISC; Irreversible sickle cells, RSC Reversible sickle cells, SC sickle cells, PBS: Peripheral Blood smear

Baral suffered from only Hb AS. Subgroups Chaudhary and Rana Tharus are from Terai region of Nepal where there is prevalence of Malaria (fig. 1 ). ${ }^{8}$

$\mathrm{Hb} \mathrm{S}$ is has been demonstrated in various tribal communities of Gujrat, India. ${ }^{3}$ The disease is found predominantly amongst certain high risk communities belonging to schedule caste, schedule tribe and other backward classes. ${ }^{6}$

Origin of $\mathrm{Hb} \mathrm{S}$ and its mutation has been seen in several locations within Africa and Asia. Sickle $\mathrm{Hb}$ containing red cells inhibits proliferation of plasmodium falciparum, and are more likely to become deformed and removed from the circulation. Recently, due to movement of populations via trade routes and the slave trade, dissemination of sickle mutation in different areas of the world took place. ${ }^{9}$ According to the study, Sickle hemoglobin seen majority in Tharus from malarial endemic region and minority of patients are of different ethnic groups of Nepal. Though malarial hypothesis explains sickle hemoglobin in Tharus, it's not answerable in other ethnic group. It has been seen that there is human migrations from malarial regions into non-malarial region. Increasing genetic disorder burdens can be seen in malarial region as well as non-malarial region in the future. This restrospective study was done without detail information i.e. family history, consanguity and migration. Prospective study can be done in large scale of patients with pertinent data.

\section{CONCLUSION}

In Nepal; $\mathrm{HbS}$ is common in certain ethnic groups where malaria is endemic. However, other ethnic group, who resides on non-endemic region, may also be suffering from HBS which compel us to screen all anemia cases taking $\mathrm{HbS}$ into consideration

\section{RECOMMENDATION}

Further study may be done to investigate and estimate sickle hemoglobin in different western and central Terai of Nepal. Genetic study and hemoglobin elcetrophoresis by HPLC technique can be used for better diagnosis. Education on sickle hemoglobin mutation and its increasing burden to particular ethnic groups may be helpful.

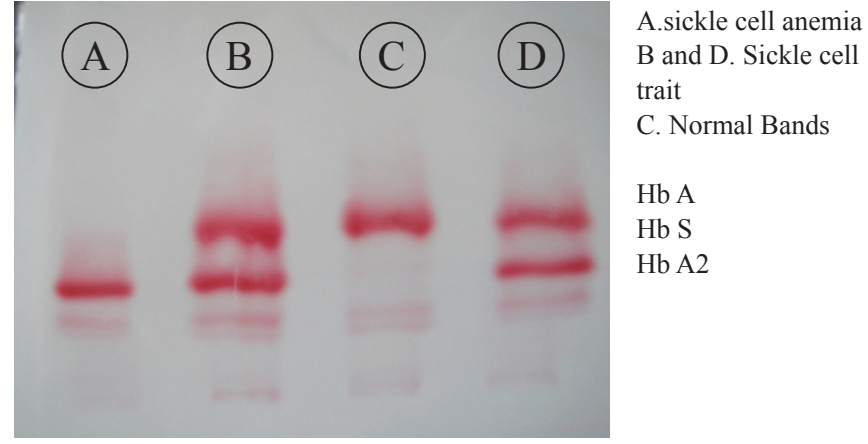

Figure 4: Cellulose Acetate electrophoresis.

\section{REFERENCES}

1. Winfred C.Wang, Sickle Cell Anemia and other Sickling Syndromes in Wintrobe's Clinical Hematology, John P. Greer, John forester, George M. Rodgers, Frixos Paraskevas, Bertil Glader, Daniel A. Arber, Robert T. Means, Vol 1, eds 12th, Wolters Kluwer/Lippincott Williams and wilkins, Philedelphia, 2009.pp1038-40.

2. Piel FB, Patil AP, Hawas RE et al. Global epidemiology of sickle haemoglobin in neonates: contemporary geostatistical model - based map and population estimates. Lancet 2013;38:142-51

3. Mohsen AF El-Hazmi, Ali M. Hazmi, Ajumand S. Warsy, Sickle cell disease in Middle East Arab Countries, Indian J Med Res 2011; 134: 597-610.

4. Kamble M, Chaturvedi P. Epidemiology of sickle cell disease in a rural hospital of central India, Indian Pediatr 2000;37:391-6.

5. Rao S, Goyal JP, Raghunath SV, Shah VB. Hematlogy profile of sickle cell disease from South Gujarat, India. Hematol Rep 2012;4: e8.

6. Shrikhande AV, Dani AA, Tijare JR, Agrawal AK. Hematological profile of sickle cell disease in central India. Indian J Hematol Blood Transfus 2007;23:92-8.

7. Shukla RN, Solanki BR, Parande AS. Sickle cell disease in India. Blood $1958 ; 13: 552-8$.

8. Krauskopff G. The Anthropology of the Tharus: An Annotated Bibliography. CNRS, Paris. pp 1-2. Available from: https://www. google.com.np/?gws_rd=cr\&ei=FAk0UuK-L8WCrgf_oDgCQ\#q= Krauskopff + G. + The + Anthropology + of + the + Tharus $\% 3 \mathrm{~A}+\mathrm{An}+\mathrm{Ann}$ otated+Bibliography.

9. Weatherall DJ. Genetic disorders of haemoglobin in Postgraduate Haematology, A. VictoR Hoffbrand, S.Mitchell Lewis, Edward G.D Tuddenham, 4th edition, Blackwell Publishing Ltd. Massachusetts, USA.1999.pp110-113. 